\title{
GROWTH AND DEVELOPMENT OF DWARF BUTIA SEEDLINGS (Butia lallemantii): SUBSTRATE AND PROPAGULE SIZE
}

\section{CRESCIMENTO E DESENVOLVIMENTO DE MUDAS DE BUTIÁ-ANÃO (Butia lallemantii): SUBSTRATO E TAMANHO DO PROPÁGULO}

\author{
Luciana Pinto Paim ${ }^{1}$ \\ Eduarda Demari Avrella ${ }^{1}$ \\ Gian Carlos Gonçalves ${ }^{2}$ \\ Marília Lazarotto ${ }^{3}$ \\ Claudimar Sidnei Fior ${ }^{4}$
}

Submetido: 30/07/2021 / Aprovado: 30/11/2021 / Publicado: 10/12/2021.

\begin{abstract}
Resumo
Butia lallemantii é uma palmeira de hábito cespitoso e caule subterrâneo, apresentando propagação assexuada. No entanto, faltam estudos relacionados às práticas de produção de mudas. O objetivo foi avaliar o crescimento e o desenvolvimento de plantas de Butia lallemantii submetidas a formulações de substratos e diâmetros de estipe. Mudas foram classificadas em duas classes de diâmetro de estipe (CDE) e dispostas nos seguintes substratos: comercial (CM); casca de arroz carbonizada (CAC); e CAC + pó de coco $(\mathrm{CAC}+\mathrm{PC}-1: 1$, v/v). Foram avaliados: número de perfilhos e de folhas pinadas (NFP), e ao final: comprimento, volume, massa fresca e seca de raízes e porcentagem de folhas vivas, durante 570 dias. Delineamento experimental foi inteiramente casualizado em esquema bifatorial (2x3), com quatro repetições. Não houve interação entre o substrato e os fatores de CDE para as variáveis do sistema foliar, entretanto, interação foi observada em todas as variáveis do sistema radicular. A classe 2 apresentou resultados superiores para NFP, e não houve substrato com variância significativa. No sistema radicular: a classe 2 e o substrato CAC permitiram resultados superiores. Portanto, os substratos CAC associados à classe 2 são adequados para o desenvolvimento de mudas de Butia lallemantii.
\end{abstract}

Palavras-chave: Hábito de crescimento cespitoso. Palmeira nativa. Recuperação de áreas degradadas. Produção de mudas.

Abstract
Butia lallemantii is a palm with a cespitous habit and subterranean stems, showing asexual
propagation. However, there is a lack of studies related to seedling production practices. The

${ }^{1}$ Doctorate in Fitotecnia, Federal University of Rio Grande do Sul, Av. Bento Gonçalves 7712, Bairro Agronomia, CEP 91540-000, Porto Alegre, RS, Brazil.

${ }^{2}$ Graduating in Agronomy, Federal University of Rio Grande do Sul, Av. Bento Gonçalves 7712, Bairro Agronomia, CEP 91540-000, Porto Alegre, RS, Brazil.

${ }^{3}$ Doctorate in Forestry Engineering, adjunct professor Engineering Center, Federal University of Pelotas, Praça Domingos Rodrigues, Bairro Centro, CEP 96010-450, Pelotas, RS, Brazil.

${ }^{4}$ Doctorate in Fitotecnia, adjunct professor in the Department of Horticulture and Forestry, Federal University of Rio Grande do Sul, Av. Bento Gonçalves 7712, Bairro Agronomia, CEP 91540-000, Porto Alegre, RS, Brazil.

*Email: lucianappaim@bol.com.br 
objective was to evaluate the growth and development of Butia lallemantii plants submitted to substrate formulations and stipe diameters. Seedlings were classified into two classes of stipe diameter (CSD) and placed on the following substrates: commercial (CM); carbonized rice husk $(\mathrm{CRH})$; and $\mathrm{CRH}+$ coconut powder $(\mathrm{CRH}+\mathrm{CP}-1: 1, \mathrm{v} / \mathrm{v})$. The following were evaluated: number of tillers and pinnate leaves (NPL), and percentage of live leaves, during 570 days, and at the end: length, volume, fresh and dry root mass. The experimental design was completely randomized in a bifactorial scheme $(2 \times 3)$, with four replications. There was no interaction between the substrate and the CSD factors for the variables of the leaf system, however, interaction was observed in all the variables of the root system. Class 2 showed superior results for NPL, and there was no substrate with significant variance. In the root system: class 2 and CRH substrate allowed superior results.

Keywords: Cespitous growth habit. Native palm. Recovery of degraded areas. Seedling production.

\section{INTRODUCTION}

The species Butia lallemantii Deble and Marchiori is popularly known as "butia-anao" or "butiazeiro-anao". This small palm belongs to the Arecaceae family and is endemic to the Pampa biome, which was described in 2006 (DEBLE e MARCHIORI, 2006). It is a conspicuous element of the western and southwestern region of Rio Grande do Sul, covering the municipalities of Santana do Livramento, Rosário do Sul, Quaraí, Alegrete, Manoel Viana, and São Francisco de Assis, being observed in the sandy fields and the sand elevations of these places (SOARES et al., 2014), as well as, in some areas affected by the sanding process. The presence of this species has also been confirmed over the fields in Uruguay (GEYMONAT e ROCHA, 2009).

This species stands out for its natural development over some sand areas. Places that present essentially sandy soils with high leaching and low natural fertility, which are under intense action of erosive processes (wind and water), impairing the establishment of vegetation in soils susceptible to these processes (SUERTEGARAY e OLIVEIRA, 2018). Despite being an environment hostile to most species, Butia lallemantii is an important alternative for the recovery of these areas, due to its adaptation to these extreme conditions and the development of peculiar characteristics (deep roots, multiplication by clumps and resistant leaves).

This palm has its own morphological characteristics in relation to the other species of the genus Butia. It can reach up to $1.0 \mathrm{~m}$ in height, showing a typical cespitous growth habit with underground stems and fruiting throughout the year (SOARES et al., 2014). Yet, its potential (artisanal products, landscaping, degraded areas recovery etc.), in addition to being an important food source for the local fauna, it is also used in the production of artisanal products such as jellies, cachaça, ice cream, among others (DEBLE e MARCHIORI, 2006; PAIM et al., 2019).

A matter of concern about the Butia lallemantii species is that its natural populations are being decimated at an extremely fast pace caused by the expansion of crops, the silviculture of exotic species (SOARES et al., 2014), and the implementation of cultivated pastures, until the current moment. As a result, this palm is found in the List of Flora Species Threatened with Extinction in Rio Grande do Sul (SEMA, 2014), lacking information both for the development and production of its seedlings, aiming at the subsequent planting and establishment in the field.

The substrate is a key factor for obtaining quality seedlings, especially the appropriate choice of components that will be used in its formulation (OLIVEIRA et al., 2017). Such composition will directly influence the seedling production process, thus, the chemical and physical properties need to be as favorable as possible for the growth and development of the species under cultivation (OLIVEIRA et al., 2014; TRAZZI et al., 2014; VIEIRA e WEBER, 
2016). The growth of seedlings and the formation of the root system are directly related to the properties of the substrate, as well as their interaction with the container and water management (KÄMPF, 2005; CECCAGNO et al., 2019a e 2019b).

Butia lallemantii propagates through clumps, in which the development of new plants occurs in its perimeter, where each of which can reach more than 60 plants. Thus, in the same clump, plants of different stem diameters occur concomitantly, related to the time of their development (PAIM et al., 2019). Seed production is very limited and difficult to access in native populations due to the great demand and attractiveness for local fauna (DEBLE e MARCHIORI, 2006; PAIM et al., 2019). Therefore, it is difficult to obtain seeds for the production of seedlings of the species.

To offer an alternative for the propagation of Butia lallemantii, we sought to relate a combination between rescued seedling size and a substrate formulation that would offer better conditions for plant growth and development in less time and with higher quality. Therefore, the present work aimed to evaluate the growth and development of Butia lallemantii plants submitted to different formulations of substrates and stem diameters, to produce seedlings for later recovery of sandy areas.

\section{MATERIAL AND METHODS}

This work started in November 2017 through the rescue of Butia lallemantii plants in natural areas at Três Nascentes Farm, located in the municipality of Alegrete, State of Rio Grande

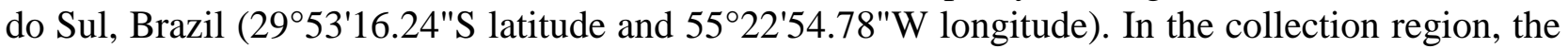
type of soil that occurs is the Entisols (SANTOS et al., 2018). The climate is characterized as moderately humid subtropical of the Cfa type, according to the Köppen classification, with a minimum annual rainfall of $1,600 \mathrm{~mm}$ distributed from 90 to 120 days. The average temperature of the coldest month varies between -3 and $18^{\circ} \mathrm{C}$ and the hottest month exceeds $22^{\circ} \mathrm{C}$ (ALVARES et al., 2013).

The seedlings were extracted from four clumps of Butia lallemantii plants that were spaced about five meters apart, with an average diameter of $1.0 \mathrm{~m}$ each, and these were located in a population with an average density of 40 clumps per hectare. When the clumps were pulled out, the soil surrounding the clumps was carefully removed from a distance of 30 to $50 \mathrm{~cm}$, in order to avoid damage to the seedlings. The seedlings were manually separated from each clump, and the leaves and roots were pruned, leaving approximately $5 \mathrm{~cm}$ of root length and $25 \mathrm{~cm}$ of shoot length (PAIM et al., 2019).

The individuals were classified into two classes of stipe diameter (CSD) (Class 1: from 3 to $7 \mathrm{~cm}$ and Class 2: from 7.1 to $10 \mathrm{~cm}$ ), which were determined according to the availability of diameters of the collected seedlings (Figure 1). The plants of these Classes 1 and 2 had an average of 1.82 and 3.15 pinned leaves per plant, respectively.

After cleaning, pruning and classification, the seedlings were placed in 1.7-L containers (size $20 \mathrm{~cm}$ in height and $12 \mathrm{~cm}$ in diameter), which were filled with the following substrates: commercial (compost based on Sphagnum peat, expanded vermiculite, carbonized rice husk, and NPK fertilizer); carbonized rice husk; and a formulation composed of carbonized rice husk and coconut powder (product resulting from the defibrillation of the Cocos nucifera L. mesocarp) $(1: 1)$.

Fertilization was carried out in a single dose at planting through the incorporation of approximately $4 \mathrm{~g} \mathrm{~L}^{-1}$ of slow-release fertilizer (Basacote Plus $9 \mathrm{M}-15-8-12+2 \mathrm{Mg}+5 \mathrm{~S}+0.4 \mathrm{Fe}$ $+0.02 \mathrm{~B}+0.02 \mathrm{Zn}+0.05 \mathrm{Cu}+0.06 \mathrm{Mn}+0.015 \mathrm{Mo}$ ), which was mixed with the substrates before 
filling the containers. Besides, $2.58 \mathrm{~g} \mathrm{~L}^{-1}$ of the mineral fertilizer NPK (5-30-15) was added to the carbonized rice husk substrates and in the formulation of carbonized rice husk and coconut powder, as an additive, as the commercial substrate has these nutrients in its composition.

Before incorporating the slow-release fertilizer and the fertilization to compensate the substrates, an aliquot of approximately three liters of each formulation was separated and analyzed in triplicates at the Substrate Laboratory of the Faculty of Agronomy of the Federal University of Rio Grande do Sul (UFRGS) (Table 1).

Next, the seedlings were taken to a greenhouse with a transparent plastic cover, aluminized screen, and 50\% luminous interception, owned by the Department of Horticulture and Silviculture of the Faculty of Agronomy at UFRGS, in Porto Alegre, RS. The seedlings remained in this environment for 570 days, with average temperature and relative humidity of $26.3^{\circ} \mathrm{C}$ and $74.7 \%$, respectively. Also, the thermal amplitude fluctuation of 26.3 to $56.8^{\circ} \mathrm{C}$ in the hottest months and from 8.6 to $18.6^{\circ} \mathrm{C}$ in the coldest months. The irrigation used in the plants was the micro-sprinkler system (water depth of $4 \mathrm{~mm} \mathrm{day}^{-1}$ ), distributed in four daily cycles of one minute each.

Seedling evaluations were carried out monthly by the same evaluator to prevent variations and experimental errors, according to the variables of the leaf system: number of emission of tillers, number of pinnate leaves formed, percentage of absence of live leaves (plants considered dead) and percentage of live leaves. Leaves that presented green pigmentation were considered alive. At the end of 570 days, the root system was evaluated: length of new emitted roots $(\mathrm{cm})$, root fresh mass $(\mathrm{g})$ and root dry mass $(\mathrm{g})$, and the total volume of roots $\left(\mathrm{cm}^{3}\right)$ according to Munguambe (2012).

The treatments were arranged in a completely randomized design (CRD), in a bifactorial scheme $(2 \times 3)$, in which the first factor corresponded to the two classes of diameter of the stipe (Class 1: from 3 to $7 \mathrm{~cm}$; and Class 2: from 7.1 to $10 \mathrm{~cm}$ ) and the second factor to the three substrate formulations (commercial, carbonized rice husk and the formulation composed of carbonized rice husk and coconut powder in equal volumetric proportions). These treatments were randomly distributed in four replications of 10 plants per plot, totaling 240 plants.

After fulfilling the assumptions of the analysis of variance (ANOVA), the data were submitted to ANOVA, followed by polynomial regression and comparison of means through the LSD test (Least Significant Difference) at the level of 5\% probability of error, using Costat ${ }^{\circledR} 6.4$ and SigmaPlot ${ }^{\circledR} 11.0$ software.

\section{RESULTS AND DISCUSSION}

The analysis of variance regarding growth and development of the leaf system of the Butia lallemantii seedlings showed the lack of interaction between the substrate factors and the stem diameter classes, for the variables number of pinnate leaves formed, number of emitted tillers, percentage of live leaves and absence of live leaves (Table 2). However, for the root system, there was interaction for data referring to all analyzed variables (Table 2).

After 570 days, it was observed that the variables related to the number of tillers, the percentage of live leaves, and the absence of live leaves were not influenced by the evaluated treatments (Table 2). Regarding the number of pinnate leaves, a superiority was found for Class 2 of diameter of the stipe (Table 3). This result is possibly caused by the fact that seedlings with a larger diameter accumulate larger amounts of reserves, as well as being older in comparison to those of a smaller diameter. This inference is based on the fact that when the seedlings were being separated from the clumps, it was observed that the plants with the smallest diameter were located 
on their periphery and those with the largest diameter were more centralized, which suggests that the new tillers emerge from the center towards the edge of the clumps.

According to Raven et al. (2014), the stems are important structures for the plants as they establish a communication between the roots and the leaves, carrying out the translocation of water and nutrients. Also, they provide support and adequate disposition of the leaves, promoting the best use of the light energy. Consequently, it is believed that this larger-diameter class has favored the appearance of a greater number of pinnate leaves from Butia lallemantii plants.

In studies carried out with this species where only stipe diameter classes were evaluated without considering other factors, Paim et al. (2019) found a higher emission of vegetative structures in plants with larger diameters of stipes. These authors claim that plants of this class would have been privileged by the high availability of nutritional reserves, resulting in the permanence of live leaves for longer periods.

In relation to experiments carried out in the field, in a sandy area, Butia lallemantii seedlings with a larger of stipe diameter showed greater adaptation and establishment (PAIM e PAIM, 2016). Thus, palm trees with a cespitous growth habit and with the presence of a larger stem diameter will promote the development of plants and superior survival in the field (PAIM et al., 2020).

The lack of significant difference for the other variables related to the development of the aerial part may be related to ecophysiological issues of the species, since its adaptation in sandy soil environments with water restriction (DEBLE e MARCHIORI, 2006), may have favored the initial formation of a larger root system. This hypothesis is supported by the higher results found for the root system of Butia lallemantii plants, highlighting the substrate carbonized rice husk factors and class two of diameter of stipe in the variables of length, volume, fresh and dry mass of roots after the 570 days (Table 4).

The vast majority of palm trees are characterized by a slow growth of their seedlings, which is no different for Butia lallemantii (PAIM et al., 2020). However, it was observed in this work that the root system was influenced by the characteristics of the substrate, which shows that, depending on the environmental condition, this growth can be accelerated. According to the results of Table 4, it is observed that the length of the roots was higher for the substrate carbonized rice husk, with an average of $20.71 \mathrm{~cm}$. The analysis of the physical characteristics of the carbonized rice husk showed an excellent low water retention capacity and a high aeration space, characterized by a higher proportion of macropores (SIMÕES et al., 2012; KRATZ et al., 2013), compared to the other formulations used. The laboratory analysis of the carbonized rice husk showed a total porosity of $86.80 \%$, within the range considered ideal by De Boodt e Verdonck (1972). In addition to allowing greater gas exchange, these larger pores also facilitate the development of the roots besides preventing the accumulation of water as they increase the drainage capacity of the substrate (ZORZETO et al., 2014).

The adequate development of the root system, reaching a larger covered area, will result in greater ion absorption capacity (TAIZ et al., 2017). Further, a good formation of the roots will favor the greater resistance of the plants, according to Behling et al. (2014), resulting in more robust plants and allowing greater adaptation to adverse conditions.

Taiz et al. (2017) claim that some plants can develop an extensive root system. Also, it can be observed in their natural habitat that the production of roots over long periods could easily exceed the development of the aerial part. Results referring to the Butia lallemantii species indicate that its roots can reach up to one meter in length (SOARES et al., 2014), however, at the collection of seedlings for the execution of this experiment, it was found the presence of individuals with a root system greater than 2.5 meters. 
It is believed that the adaptation of this species to the extreme conditions of sandy soils, that is, places of high leaching, low natural fertility, the greater predominance of macropores, in addition to an intense action of erosive processes (wind and water), which harm the establishment of plants (SUERTEGARAY e OLIVEIRA, 2018), was acquired throughout its evolution. This explains the growth of its roots in search of water and nutrients at great depths since in the superficial layers, the soil is composed of sand, which results in extremely low water retention.

Plants with a larger diameter of stipe (class 2) showed higher results in all variables analyzed for the root system. As already mentioned for the similar result in the development of the aerial part, this greater development of the root system is explained both by the possible older age of the plants and by the greater accumulation of reserves in the stem. Similar results were found by Paim et al. (2020), who pointed to greater development of more vigorous plants when seedlings with a larger diameter of stipes were used.

According to the results of the variables referring to the leaf and root system of the Butia lallemantii seedlings, it was observed the efficiency of the substrate composed of carbonized rice husks and the Class 2 of diameter of the stipe, with a circumference of 7.1 to $10 \mathrm{~cm}$. The substrate is an extremely important factor during the seedling production process and must have adequate characteristics of high porosity, adequate structure, high water retention, among others (CALDEIRA et al., 2013), to assist in the development of the plant in a container.

The carbonized rice husk stands out for its greater drainage and favorable aeration for the development of the seedling root system, in addition to being a low-cost organic waste (SILVA et al., 2012; CALDEIRA et al., 2013). However, there is a need to pay attention to the low availability of nutrients in this component, as well as its high-drainage capacity, which must be compensated through adequate fertilization and water management.

These results are very important for the Butia genus, as studies focusing on these species are still rare, which makes it difficult to improve the seedling production process (LUZ et al., 2011; BRAHM et al., 2013). The relevance of the production of Butia lallemantii seedlings is emphasized, as this species is adapted to sandy soil environments with low water availability and affected by the strong degradation of the sanding process, therefore, the use of these seedlings in the recovery of these locations becomes promising. In addition, there are possibilities of using the species for other purposes, such as gardens and external landscaping, since it stands out for its ornamental aspect and its growth habit can make planting feasible in areas where plants are sought in dense massifs, however with restricted height.

\section{Conclusions}

The carbonized rice husk substrate associated with the largest class of stipe diameter is the most suitable treatment for the development of Butia lallemantii seedlings.

\section{ACKNOWLEDGMENTS}

The present study was carried out with support from CAPES (Higher Education Personnel Improvement Coordination), $\mathrm{CNPq}$ (National Council for Scientific and Technological Development) and FAPERGS (Foundation for Research Support of the State of Rio Grande do Sul) that contributed to the development of the work.

The authors inform that there is no conflict of interest in the research and publication of the manuscript. 


\section{REFERÊNCIAS}

ALVARES CA, STAPE JL, SENTELHAS PC, GONÇALVES JLM, SPAVOREK G. Köppen's climate classification map for Brazil. Meteorologische Zeitschrift, v. 22, n. 6, p. 711-728, 2013.

BEHLING M, NEVES JCL, BARROS NF, KISHIMOTO CB, SMITH L. Eficiência de utilização de nutrientes para formação de raízes finas e médias em povoamento de teca. Revista Árvore, v. 38, p. 837-846, 2014.

BRAHM RU, MEDEIROS CAB, CARDOSO JH, REISSER C. Avaliação do efeito de diferentes substratos sobre o desenvolvimento de Euterpe edulis (Mart.) e Roystonea regia (Kunth). Revista Brasileira de Agroecologia, v. 8, n. 2, p. 148-160, 2013.

BRASIL. Secretaria Estadual do Meio Ambiente. Táxons da flora nativa do Estado Rio Grande do Sul ameaçadas de extinção, 2014. Porto Alegre: FZB. Available

at: http://www.mcn.fzb.rs.gov.br/upload/20141208161010anexo_i_taxons_da_flora_nativa_do_est ado_rio_grande_do_sul_ameacadas_de_extincao_1_.pdf . Accessed on: January 25th, 2021.

CALDEIRA MVW, DELARMELINA WM, FARIA JCT, JUVANHOL RS. Substratos alternativos na produção de mudas de Chamaecrista desvauxii. Revista Árvore, v. 37, n. 1, p. 3139, 2013.

CECCAGNO H, SOUZA PVD, SCHÄFER G, AVRELLA ED, FIOR CS. Potential of Pinus elliottii Engelm. needles as substrate conditioner for the production of "Fepagro C37 Reck" Citrus rootstocks. Revista Brasileira de Fruticultura, v. 41, n. 3, (e-039), 2019a.

CECCAGNO H, SOUZA PVD, SCHÄFER G, AVRELLA ED, FIOR CS, SCHWARZ S. F. Potential of Pinus sp. needles for use as substrate conditioners in the production of 'Trifoliata' rootstock in greenhouses. Revista Chapingo, v. 25, n. 1, p. 1-16, 2019 b.

DEBLE LP, MARCHIORI JNC. Butia lallemantii, uma nova Arecaceae do Brasil. Balduinia, 9: $1-3,2006$.

DE BOODT M, VERDONCK O. The physical properties of the substrates in horticulture. Acta Horticulturae, v. 26, p 37-44, 1972.

GEYMONAT G, ROCHA N. Butia: Ecossistema único em el mundo. Castillos, Rocha, Uruguay: Casa Ambiental, 2009. 405 p.

KÄMPF AN. Produção comercial de plantas ornamentais. 2 ed. Guaíba: Agrolivros, 2005. 254 p.

KRATZ D, WENDLING I, NOGUEIRA AC, SOUZA PV. Propriedades físicas e químicas de substratos renováveis. Revista Árvore, v. 37, n. 6, p. 1103-1113, 2013. 
LUZ PB, PAIVA PDO, TAVARES AR, KANASHIRO S, AGUIAR FF. Efeito de diferentes substratos e adubação fosfatada no crescimento de mudas de Rhapis excelsa (Thunb.) A. Henry Ex. Rehder (Palmeira-ráfia). Revista Brasileira de Horticultura Ornamental, v. 17, n. 1, p. 37 42, 2011.

MUNGUAMBE JF. Qualidade morfológica de mudas clonais de eucalipto na fase de expedição em viveiros comerciais. 2012. 73p. Master Dissertation. Universidade Federal de Lavras, Lavras, 2012.

OLIVEIRA FA, OLIVEIRA JM, NETA MLS, OLIVEIRA MKT, ALVES RC. Substrato e bioestimulante na produção de mudas de maxixeiro. Horticultura brasileira, v. 35, n. 1, p. 141146, 2017.

OLIVEIRA LC, COSTA E, SOBRINHO MFO, BINOTT FFS, MARUYAMA WI, ALVES AC. Esterco bovino e fibra de coco na formação de mudas de baruzeiro. Rev. Agric. Neotrop., v. 1, n. 2, p. 42-51, 2014.

PAIM LP, AVRELLA ED, FREITAS EM, FIOR CS. Collection of plants in situ and conditioning of Butia lallemantii seedlings. Floresta e Ambiente, v. 26, n. 2, e20170579, 2019.

PAIM LP, AVRELLA ED, FREITAS EM, FIOR CS. Revegetación de suelo arenizado con Butia lallemantii en el suroeste del estado de Rio Grande do Sul, Brasil. Bosque, v. 41, n. 1, p. 35-43, 2020.

PAIM LP, PAIM MP. Uso de mudas de Butia lallemantii (Deble \& Marchiori) para recuperar áreas degradadas por arenização no município de Alegrete-RS. Revista Congrega, v. 13, p. 984994, 2016.

RAVEN PH, EICHHORN SE, EVERT RF. Biologia vegetal. 8 ed. Guanabara Koogan, 2014. 867 p.

SANTOS HG, JACOMINE PKT, ANJOS LHC, OLIVEIRA VA, LUMBRERAS JF, COELHO MR, ALMEIDA JA, FILHO JCA, OLIVEIRA JB, CUNHA TJF. Sistema Brasileiro de

Classificação de Solos. 5 ed rev. e amp. Brasília: Embrapa, 2018. 356 p.

SILVA RBG, SIMÕES D, SILVA MR. Qualidade de mudas clonais de Eucalyptus urophylla x E. grandis em função do substrato. Revista Bras. Eng. Agríc. Ambiental, v. 16, n. 3, p. 297-302, 2012.

SIMÕES D, SILVA RBG, SILVA MR. Composição do substrato sobre o desenvolvimento, qualidade e custo de produção de mudas de Eucalyptus grandis Hill ex Maiden $\times$ Eucalyptus urophylla S. T. Blake. Ciência Florestal, v. 22, n. 1, p. 91-100, 2012. 
SOARES KP, LONGHI SJ, WITECK LN, ASSIS LC. Palmeiras (Arecaceae) no Rio Grande do Sul, Brasil. Rodriguésia, v. 65, n. 1, p. 113-139, 2014.

SUERTEGARAY DMA, OLIVEIRA MG. Arenização, areais e políticas de ordenamento territorial. Cadernos de Geografia, v. 38, p. 69-76, 2018.

TAIZ L, ZEIGER E, MOLLER I, MURPHY A. Fisiologia e desenvolvimento vegetal. 6 ed. Porto Alegre: Artmed, 2017. 888 p.

TRAZZI PA, DELARMELINA WM, CALDEIRA MVW. Concentração e qualidade de nutrientes em mudas de Teca produzidas em substratos orgânicos. Ecol. Nut. Flor., v. 2, n. 1, p. 19-31, 2014.

VIEIRA CR, WEBER OLS. Produção de mudas de eucalipto em diferentes composições de substratos. Rev. Estudos Amb., v. 18, n. 2, p. 25-34, 2016.

ZORZETO TQ, DECHEN SCF, ABREU MF, JÚNIOR FF. Caracterização física de substratos para plantas. Bragantia, v. 73, n. 3, p. 300-311, 2014.

Figure 1. Classification of Butia lallemantii seedlings in two classes of diameter of the stipe, where Class 1 is from 3 to $7 \mathrm{~cm}(\mathrm{~A})$ and Class 2, from 7.1 to $10 \mathrm{~cm}(\mathrm{~B})$.

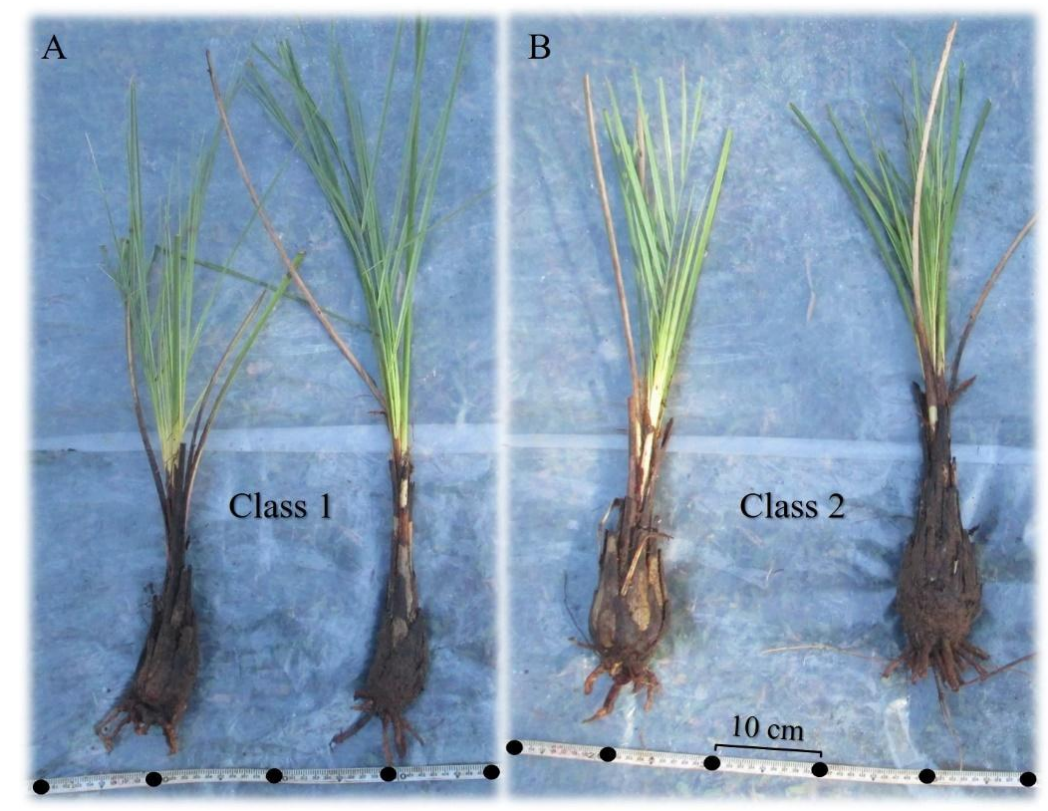


Table 1. Physical and chemical properties of the commercial substrates, carbonized rice husk, and the carbonized rice husk and coconut powder formulation $(1: 1, \mathrm{v} / \mathrm{v})$.

\begin{tabular}{cccc}
\hline $\begin{array}{c}\text { Physical and chemical } \\
\text { properties }\end{array}$ & Commercial & CRH & CRH + CP (1:1) \\
\hline WD $\left(\mathrm{kg} \mathrm{m}^{-3}\right)$ & 256.29 & 367.00 & 293.57 \\
DD $\left(\mathrm{kg} \mathrm{m}^{-3}\right)$ & 142.75 & 151.97 & 107.00 \\
$\mathrm{CH}(\%)$ & 44.30 & 58.59 & 63.55 \\
$\mathrm{TP}(\%)$ & 77.07 & 86.80 & 86.19 \\
$\mathrm{AS}(\%)$ & 31.15 & 64.27 & 56.44 \\
$\mathrm{EAW}(\%)$ & 13.12 & 9.99 & 14.38 \\
$\mathrm{BW}(\%)$ & 2.80 & 1.25 & 1.39 \\
$\mathrm{RW}(\%)$ & 30.00 & 11.29 & 13.99 \\
$\mathrm{AW}(\%)$ & 15.92 & 10.24 & 6.77 \\
pH $\left(\mathrm{H}_{2} \mathrm{O}\right)$ & 6.04 & 7.17 & 0.31 \\
$\mathrm{EC}\left(\mathrm{mS} \mathrm{cm}^{-1}\right)$ & 0.32 & 0.10 & \\
\hline
\end{tabular}

$\mathrm{CRH}=$ carbonized rice husk; $\mathrm{CP}=$ coconut powder; $\mathrm{WD}=$ wet density; $\mathrm{DD}=$ dry density; $\mathrm{CH}=$ current humidity; $\mathrm{TP}$ $=$ total porosity; $\mathrm{AS}=$ aeration space $\mathrm{EAW}=$ easily available water; $\mathrm{BW}=$ buffering water; $\mathrm{RW}=$ remaining water; $\mathrm{AW}=$ available water; $\mathrm{pH}=$ hydrogenionic potential, determined in water $1: 5(\mathrm{v} / \mathrm{v}) ; \mathrm{EC}=$ electrical conductivity obtained in a 1:5 (v/v) solution.

Table 2. Analysis of variance of the number of pinnate leaves (NPL) and tillers (NT), percentage of live leaves (PLL) and absence of live leaves (ALL), root length (RL), root volume (RV), root fresh mass (RFM) and root dry mass (RDM), according to the commercial substrates, carbonized rice husk and the formulation of carbonized rice husk and coconut powder $(1: 1, \mathrm{v} / \mathrm{v})$ and the two classes diameter of the stipe (Class 1: from 3 to $7 \mathrm{~cm}$; and class 2: from 7.1 to $10 \mathrm{~cm}$ ).

\begin{tabular}{cccccc}
\hline VA & SB & CDS & INT & CV $(\%)$ & OA \\
\hline NPL & $\mathrm{p}=0.0532^{\mathrm{ns}}$ & $\mathrm{p}<0.041$ & $\mathrm{p}=0.5791^{\mathrm{ns}}$ & 36.60 & 0.60 \\
NT & $\mathrm{p}=0.5410^{\mathrm{ns}}$ & $\mathrm{p}=0.6839^{\mathrm{ns}}$ & $\mathrm{p}=0.4178^{\mathrm{ns}}$ & 30.10 & 0.74 \\
PLL $(\%)$ & $\mathrm{p}=0.1475^{\mathrm{ns}}$ & $\mathrm{p}=0.8616^{\mathrm{ns}}$ & $\mathrm{p}=0.3209^{\mathrm{ns}}$ & 37.43 & 25 \\
ALL $(\%)$ & $\mathrm{p}=0.1475^{\mathrm{ns}}$ & $\mathrm{p}=0.8616^{\mathrm{ns}}$ & $\mathrm{p}=0.3209^{\mathrm{ns}}$ & 12.25 & 75 \\
RL $(\mathrm{cm})$ & $\mathrm{p}<0.01$ & $\mathrm{p}<0.01$ & $\mathrm{p}<0.02$ & 19.93 & 10.20 \\
RV $\left(\mathrm{cm}^{3}\right)$ & $\mathrm{p}<0.01$ & $\mathrm{p}<0.02$ & $\mathrm{p}<0.01$ & 20.43 & 15.96 \\
RFM $(\mathrm{g})$ & $\mathrm{p}<0.02$ & $\mathrm{p}<0.02$ & $\mathrm{p}<0.01$ & 22.35 & 9.64 \\
\hline
\end{tabular}

${ }^{n s}$ not significant at $5 \%$ probability of error; VA = variables; $\mathrm{SB}=$ substrates; $\mathrm{CDS}=$ classes diameter of the stipe; INT = interaction; $\mathrm{CV}=$ coefficient of variation; $\mathrm{OA}=$ overall average. 
Table 3. Number of pinnate leaves (NPL) of Butia lallemantii plants, systematized in two classes of the diameter of stipe, at the end of 570 days.

\begin{tabular}{cc}
\hline Classes diameter of the stipe & NPL \\
\hline 1 & $0.48 \mathrm{~b}$ \\
2 & $0.71 \mathrm{a}$ \\
\hline $\mathrm{CV}(\%)$ & 36.60 \\
\hline P-value & $<0.041$ \\
\hline
\end{tabular}

Class $1=$ from 3 to $7 \mathrm{~cm}$; and class $2=$ from 7.1 to $10 \mathrm{~cm}$; $\mathrm{CV}=$ coefficient of variation. *Means followed by the same lower case letter in the column do not differ statistically by the LSD test at the level of $5 \%$ probability of error.

Table 4. Root length (RL), root volume (RV), root fresh mass (RFM), root dry matter (RDM), according to the commercial substrates, carbonized rice husk $(\mathrm{CRH})$, and the formulation of carbonized rice husk and coconut powder $(\mathrm{CRH}+\mathrm{CP})(1: 1, \mathrm{v} / \mathrm{v})$ and the two classes of diameter stipe (Class 1: 3 to $7 \mathrm{~cm}$ and Class 2: 7.1 to $10 \mathrm{~cm}$ ), after 570 days.

\begin{tabular}{cccccc}
\hline SB & CDS & RL $(\mathrm{cm})$ & RV $\left(\mathrm{cm}^{3}\right)$ & RFM $(\mathrm{g})$ & RDM $(\mathrm{g})$ \\
\hline $\mathrm{CM}$ & & $4.53 \mathrm{Bb}$ & $8.91 \mathrm{Ab}$ & $4.85 \mathrm{Ab}$ & $0.78 \mathrm{Ab}$ \\
$\mathrm{CRH}$ & \multirow{2}{*}{$5.84 \mathrm{Ab}$} & $10.23 \mathrm{Ab}$ & $6.67 \mathrm{Ab}$ & $1.23 \mathrm{Ab}$ \\
$\mathrm{CRH}+\mathrm{CP}$ & & $3.51 \mathrm{Cb}$ & $6.63 \mathrm{Bb}$ & $2.52 \mathrm{Bb}$ & $0.46 \mathrm{Bb}$ \\
\hline $\mathrm{CM}$ & & $8.90 \mathrm{Ca}$ & $15.77 \mathrm{Ca}$ & $8.65 \mathrm{Ca}$ & $1.42 \mathrm{Ca}$ \\
$\mathrm{CRH}$ & 2 & $20.71 \mathrm{Aa}$ & $28.14 \mathrm{Aa}$ & $18.74 \mathrm{Aa}$ & $4.43 \mathrm{Aa}$ \\
$\mathrm{CRH}+\mathrm{CP}$ & & $17.70 \mathrm{Ba}$ & $26.06 \mathrm{Ba}$ & $16.39 \mathrm{Ba}$ & $3.66 \mathrm{Ba}$ \\
\hline
\end{tabular}

$\mathrm{SB}=$ substrates; $\mathrm{CDS}=$ classes diameter of the stipe; $\mathrm{CM}=$ commercial. $*$ In the column, means of substrates followed by letters equal to uppercase and means followed by lowercase letters between classes, do not differ by the LSD test $(5 \%)$. 